\title{
Factors Affecting Small and Medium Enterprises Success: An Exploratory Study
}

\author{
Abdul Karim Kanaan Jebna ${ }^{*}$, Ahmad Suhaimi Baharudina \\ ${ }^{a}$ School of Computer Sciences, Universiti Sains Malaysia, Penang, Malaysia \\ *Corresponding author: a.kanaan@msn.com
}

Article history

Received :4 April 2013

Received in revised form : 25 July 2013

Accepted :15 October 2013

\begin{abstract}
Small and medium enterprises (SMEs) are the main contributor toward prospering the Malaysian economy [1]. Despite the fact that Malaysia is a fast growing economy in South-East Asia, death of SMEs is unavoidable. An exploratory study was conducted to investigate the factors that have an impact on business performance and success in Malaysia. Interviews with SMEs from different industries were conducted. Several factors were found to contribute to the success of business. The factors are classified into financial and non-financial determinants. These factors include customer satisfaction, service quality, experience, business expansion, competitor orientation, solving problems, cash flow, and the amount of sales and revenue. Building on these interviews, a discussion and conclusion have been provided.
\end{abstract}

Keywords: Business success; business failure; entrepreneurs; small and medium enterprises; SMEs; financial and non-financial factors; Malaysia

(C) 2013 Penerbit UTM Press. All rights reserved.

\subsection{INTRODUCTION}

In Malaysia, SMEs are the main contributor of bolstering the Malaysian economic [1, 2]. Since the early 1970s, the Malaysian government has started to pay an attention toward SMEs' development [3]. SMEs contribute to $97.3 \%$ of the total establishments in Malaysia [4]. In addition, they contribute to $31 \%$ of the Gross Domestic Product (GDP) of the nation [1], where GDP is the total market value of services and products generated by the capital and workers within the borders of a country during a specific time span, which is generally a year [5]. Furthermore, SMEs play a significant role on both employment and export sectors. They account for $56 \%$ in the former and $19 \%$ for the latter [1].

Based on the economic census report conducted by the Department of Statistics [4] in 2011, the results revealed that the total number of SMEs in Malaysia is 645,136 which accounts for 97.3 per cent of total business establishments; whereas, large establishments represent only 2.7 per cent $(17,803)$. Regarding gross output, SMEs contribute 28.5 per cent or RM 507,089 million. In addition, SMEs employ 3,669,259 persons.

Although Malaysia is a fast-developing country in SouthEast Asia [6], recent studies revealed that $13 \%$ of entrepreneurs ended their operations in 2005 after 5 years of their organizational inception [7]. In spite of the fact that there is no reliable figure, the expected failure rate of small and medium enterprises (SMEs) is even higher, about 60\% [3, 8-10]. In addition, according to SME Corp. [11], about $42 \%$ of the manufacturing firms, which exist in 2000, ceased their operations in 2005, and most of them were micro-enterprises. It is stated that many of SMEs in Malaysia could not stay in market with the competitive enterprises [9]. The rate of SMEs failure in Malaysia is inevitable; therefore, investigating the factors that can enhance the rate of new business success in Malaysia is crucial. If the rate of failure businesses is not solved, Malaysia might face harmful social and economic consequences that may affect its industrial development [7].

As survival is the contrary status of failure [12] and survival is a constitutive indicator of success [13, 14], examining the factors which contribute to business success is useful to determine the factors of business failure because the deficiency of success factors will lead to failure business. Therefore, business success and business failure studies contribute toward the same objective. This objective is to determine the factors which case business failure toward avoid them to maintain survival and achieve success

The purpose of this research note is to determine the success factors of SMEs in Malaysia as perceived by SMEs owners and managers surveyed by interviews. The individuals were asked questions to highlight the problems that their business faces along with their perception of their business performance and success.

\subsection{RESEARCH METHODS}

Interviews were conducted in Pulau Pinang (Penang Island), Malaysia, with owners and managers of small businesses. The 
investigation was a part of an ongoing research focusing on SME success in Malaysia in Universiti Sains Malaysia.

In order to understand business performance and success of SMEs, an exploratory study was carried out depending on faceto-face interviews with SMEs' owners. Details of the interviews are shown in the paper. Building on these interviews, the finding and discussion shed lights on different factors that affect business success. Besides, a frequency table has been produced to illustrate the findings and discussion.

Businesses included in the study were conveniently selected. Five of the interview participants are business founders or business partners; while, one is a business manager, and the other is a member of a family business.

The interview was semi-structured and the included questions were regarding description of the business, the number of years the business has been running, the number of working staff, the problems faced in the business, the meaning of success from the respondents' perspective, and the way of measuring business performance.

\subsection{FINDINGS}

\subsection{Background of the SMEs}

A total of seven interviews were carried out. The SMEs for this study are from different industries: pharmacy, wearing apparel, stationery, printing shop, clothes shop, and manufacturer of wearing apparel. In addition, most of these SMEs have been in business for 10 years or less; however, only one SME has been running for over 13 years. Five interviewees were sole owners or owner partners of their businesses, but, in two cases, the interviewees were not the owners: one was a manager and the other was a member of a family business.

\subsection{Interviews}

\subsubsection{Interview with $\mathrm{SME}$ “ $A$ ”}

The interview with SME "A" was conducted on October 13, 2012; he was the owner of the business, a stationery shop. The business has been in operation for over 2 years. Its staff includes three employees in addition to the owner.

Although the business started 2 years ago, the owner had previous experiences. When the business initiated, he was mature enough to embark on and run his own business. In addition to the previous experience, the owner talked about the importance of the location of the business as an essential criterion that a person should take into account when running a new business.

Regarding problems, the owner stated that he had faced problems in terms of shortage of payments to suppliers. However, he had solved the problems by a loan from a bank.

In addition, the owner has emphasized the importance of customers. He justified that customers are the real owners of a business and not the managers or the owners, as customers are the money holders. Thus, if customers are satisfied, they pay money that keeps the business running. Besides, the business can pay suppliers. Therefore, customer satisfaction is the focus and spot that the business should care about to achieve success, especially in retailers rather wholesalers because wholesalers sell in block, while retailers sell bit by bit. As a result, customer satisfaction is an indicator of business performance and success.

\subsubsection{Interview with $\mathrm{SME}$ "B"}

The interview with SME "B" was conducted on October 13, 2012; he was a member of family business. The business was associated with a photocopy shop that did photocopying and binding hardcover jobs. The business has been running for about 10 years. The business includes four staff members.

The interviewee stressed that service quality is an essential element on which business performance and success are based. Quality is what differentiates one business from another. In addition, he drew attention to machinery experience as an important element for good quality, as experience helps the owner prepare printers well so that quality is guaranteed. In other words, if the business runner does not have the needed experience, i.e., machinery experience in this case, the business cannot maintain good quality service. As a result, experience and service quality are considered crucial to achieve success.

\subsubsection{Interview with $\mathrm{SME}$ " $C$ "}

The interview with the owner of SME " $\mathrm{C}$ " was conducted October 13, 2012; it was a clothes shop. The business started in 1999, i.e., over 13 years back. The business includes four staff members and the owner.

Regarding the business performance, the owner depends on the amount of sales to compare production of his business every month. In addition, at the end of the year, a graph is generated regarding the sales throughout the year to help recognize the success of the business through time.

However, the owner stated that their business is seasonal. That means performance is different depending on seasons. For example, during "Hari Raya" (Eid al-Fitr) and other festivals, the sales are higher as compared to that in other periods. On the other hand, in monsoon, people do not like leaving their houses even in weekends; therefore, fewer sales are made by the shop. Therefore, the owner should be aware of these different seasons in order to devise a plan to target these seasons and take advantage of them to make more profits. In terms of defining success, the owner considers a business that can cover its costs, have savings, and establish more branches.

\subsubsection{Interview with $S M E$ " $D$ "}

The interview with the owner of SME "D" was conducted on October 13, 2012; it was clothes shop where women's apparel clothes were sold, especially Muslim women clothes such as scarves. The business has been running for 10 years. The owner is Turkish. He came to Malaysia 10 years ago.

He shed a light on the connection between retailers and factories. The performance of retailers reflects the performance of factories since higher sales of retailers means higher performance of factories. That is because of the simple fact that when retailers sell goods, factories have high request on products; thus, both make good profits and prospers.

Moreover, the owner claimed that businesses are seasonal, where a business prospers and makes good profit during certain times of a year such as Ramadan, when Muslims shop for the "Eid al-Fitr" festival. Regarding business success, the owner considered customer satisfaction as an important factor of success.

\subsubsection{Interview with $S M E$ " $E$ "}

The interview was held with the main manager on October 15, 2012; it was a print shop. The business initiated in year 2010 . 
The main customers of the SME are Universiti Sains Malaysia (USM) students.

The performance of the business is measured by the amount of sales. The amount of sales is an indicator that refers to the level of business performance; the higher the sales the better is the performance that the business maintains.

As mentioned, USM students are the main customers of the business; therefore, the business is affected by holidays as students leave their university and go to their hometowns.

Finally, good sales mean success or, in other words, the amount of sales a business achieved determines whether a business is successful or not.

\subsubsection{Interview with SME “F”}

SME " $F$ " is a pharmacy that promotes drugs and health and beauty products. The business was established over 2 years back.

With regard to the problems encountered by the business, the owner stated that the business face issues such as product sourcing (suppliers), pricing, and marketing budget. Pricing is related to competition as doctors give medicines to patients so that patients need not go to pharmacies. To respond to this issue, pricing is an important way that attracts customers to buy from the pharmacy. These problems never end.

The owner considers many factors to indicate whether a business is successful or not. These factors are customer satisfaction, good revenue, and open-change pharmacy outlets (branches).

\subsubsection{Interview with $S M E$ “ $G$ ”}

The Interview with SME "G" was conducted on October 13, 2012. The business manufactures and sells wearing apparel. The business has been working for 10 years and includes four staff.

The owner stated that problems always exist and that being patient is very important to find solutions. In other words, all problems have solutions, and it is important that owners be patient to find solutions.

In terms of measuring the business, financial returns and achievements show whether a business is going well or not.

\subsection{DISCUSSION}

This discussion covers some factors of business success. Success and business performance are sometimes overlapped because success is bound with business performance. In other words, success usually indicates that a business is performing well. However, SMEs have different aspects and elements to appraise their performance.

The factors can be classified under financial- and nonfinancial-oriented aspects. Financial causes of business success are cash flow and amount of sales or revenue. Non-financial contributors of business success are customer satisfaction, experience, open-changed outlets, competition, service quality, and solving problems. Table 1 shows the factors mentioned by SMEs during the interviews with their appearance frequencies from different SMEs.

There is no doubt that financial resources are essential to run a business as well as to secure its survival for long time. Consequently, lack of financial resources may lead to the demise of a business, because, for instance, a business may face critical problems in paying its suppliers. Table 1 indicates that financial determinants are the most cited causes of business success.
Many owners and managers, for instance, have emphasized that amount of sales are important to determine whether the business is doing well or not. In other words, the more the amount of sales a business makes, the better the business performance is. In addition, lack of cash flow can lead to difficulties of paying suppliers and eventually end with business failure.

Consequently, cash flow is important to cover their expenditures and pay their suppliers, so that the business can survive and achieve success.

Table 1 Factors of business success

\begin{tabular}{lcc}
\hline \multicolumn{1}{c}{ Factor } & Frequency & Category \\
\hline Cash flow & 3 & Financial \\
Amount of sales/Revenue & 5 & Financial \\
Competitor observation & 1 & Non-financial \\
Customer satisfaction & 3 & Non-financial \\
Experience & 3 & Non-financial \\
Service quality & 1 & Non-financial \\
Open-change outlets & 2 & Non-financial \\
Solving problems & 1 & Non-financial \\
\hline
\end{tabular}

In terms of non-financial determinants, customer satisfaction and experience are the most important factors contributing to business success. Customers' satisfaction plays an essential role in the success of business owners, since customers are "the money holders," as the owner of stationery stated. Two SMEs mentioned the role of customer satisfaction to achieve success. A stationery shop owner emphasized that customers are like owners because they are the money providers for a business. Therefore, if they are satisfied, the retention of customers will be higher.

Experience is emphasized by SMEs in different contexts as an indicator of business success. The owner of a printing shop referred to experience as a technical knowledge in machinery. A person needs to prepare printers to perform well, therefore quality of the service is guaranteed. However, the owners of a clothes shop referred to the industry knowledge of seasonal performance of a business. Accordingly, an owner becomes aware of the suitable times during a year when products have higher demands than other times. Thus, advantage can be taken to promote their product and services within a holistic perspective of the appropriate time to do so.

Perceiving competitors actions in order to take reactions is considered as one of the contributors of venture success. For example, a pharmacy retailer mentioned that doctors or physicians are their main competitors because they provide their patients with medicines so that patients need not go to pharmacies for prescriptions.

However, problems are endless, as the owner of wearing apparel manufacture claimed; therefore, business owners should be patient and try to find solutions. Therefore, solving problems is very important to overcome issues and achieve success.

Service quality is another indicator of business performance because the quality is considered as an attractor for customers. SME "B" claimed that printing quality is essential in their business.

Finally, branches mentioned by the owner of the pharmacy referred to the number of branches a business can open to promote its products or services.

To recap, based on the interviews, business success includes financial and non-financial factors. Financial factors 
include revenue and amount of sales. Financial factors are prominent in any business seeking profit; in addition, they are indicators of business success. The more revenue and amount of sales a business achieve, the more successful a business is considered. Non-financial factors include customer satisfaction, experience, open-change outlets, service quality, competitor observation, and solving problems.

\subsection{CONCLUSION}

The discussion based on the interviews showed perspectives of different SMEs regarding business performance and success Customer satisfaction, service quality, experience, expanding, and amount of sales and revenue are business success indicators. Therefore, a research study should be carried out to investigate the impact of these different factors on business success and develop a model that determines business success. This model can then be applied by SMEs to decrease the death rate of SMEs in Malaysia.

As the failure rate is non-trivial in Malaysia, conducting studies in order to understand the factors that lead to business success are significant to avoid failure, maintain survival, and achieve success. Obtaining the perceptions of the factors of business failure from managers and owners resulted in several useful insights.

Moreover, the reasons cited by participants for SME success can be classified into financial and non-financial determinants. Many participants referred to financial elements such as the amount of sales as the primary cause of business success.

Consequently, suggestion could be drawn to reduce the number of business failure. Cash flow, for instance, is important to maintain and achieve success. Businesses should not spend all their cash and ensure that they save sufficient cash to pay their suppliers and cover their expenditure.

Besides, business owners and managers should be aware of the importance of customer satisfaction and experience in order to boost their businesses' performance to achieve success. For instance, owners could try to gain and possess the required experiences before establishing their SMEs in order to guarantee a better chance of success. In other words, would-be business founders could work in other firms in order to gain experience needed to be able to have better chance of success

\section{Acknowledgments}

I would like to thank my parents. Besides, thanks to my doctor Dr. Ahmad Suhaimi Baharudin. Moreover, I thank all people, especially, Mr. Yousef W.H. Abuhassira, who helped me in my work and Mr. Khaled Saleem.

\section{References}

[1] SME Corp. 2010. SME Annual Report 2009/10. Kuala Lumpur Sentral, Malaysia: Small and Medium Enterprise Malaysia (SME Corp. Malaysia).

[2] Said, J., E. K. Ghani, and Z. Ibrahim. 2011. Assessment of Computerized Management Accounting System Among Small and Medium Size Construction Companies. European Journal of Economics, Finance \& Administrative Sciences. 39: 32-39.

[3] Khalique, M. 2011. Do Malaysia and Pakistan are Suitable for A Comparative Study Of SMEs: An Intellectual Capital Perspective? Interdisciplinary Journal of Contemporary Research in Business. 3(8): 98-107.

[4] Department of Statistics. 2012. Economic Census 2011 Profile of Small and Medium Enterprise. Putrajaya, Malaysia: Department of Statistics Malaysia.

[5] Bygrave, W. D. and A. Zacharakis. 2010. Entrepreneurship. John Wiley \& Sons.

[6] Sambasivan, M., M. Abdul, and Y. Yusop. 2009. Impact of Personal Qualities and Management Skills of Entrepreneurs on Venture Performance in Malaysia: Opportunity Recognition Skills As A Mediating Factor. Technovation. 29(11): 798-805.

[7] Abdullah, F., J. Hamali, A. R. Deen, G. Saban, and A. Z. A. Abdurahman. 2009. Developing A Framework of Success of Bumiputera Entrepreneurs. Journal of Enterprising Communities: People and Places in the Global Economy. 3(1): 8-24.

[8] MDTCA. PUNB Perkenal Skim Usahawan Pemborong [Online] Available: http://kpdnkk.bernama.com/newsBm.php?id=180227.

[9] Khalique, M., A. H. M. Isa, J. A. N. Shaari, and A. Ageel. 2011 Challenges Faced By the Small And Medium Enterprises (SMEs) in Malaysia: An Intellectual Capital Perspective. International Journal of Current Research. 3(6): 398-401.

[10] Ahmad, N. H., and P. S. Seet. 2009. Dissecting Behaviours Associated with Business Failure: A Qualitative Study of SME Owners in Malaysia And Australia. Asian Social Science. 5(9): 98-104.

[11] SME Corp. 2012. Summary SME Masterplan 2012-2020, Kuala Lumpur: Small and Medium Enterprise Corporation Malaysia (SME Corp. Malaysia).

[12] Chrisman, J. J., A. Bauerschmidt, and C. W. Hofer. 1999. The Determinants of New Venture Performance: An Extended Model. Entrepreneurship Theory and Practice. 23: 5-30.

[13] Brüderl, J., and R. Schüssler. 1990. Organizational mortality: The Liabilities of Newness and Adolescence. Administrative Science Quarterly. 35: 530-547.

[14] Korunka, C., A. Kessler, H. Frank, and M. Lueger. 2010. Personal Characteristics, Resources, and Environment as Predictors of Business Survival. Journal of Occupational and Organizational Psychology. 83: $1025-1051$. 